\title{
TOTAL BIAYA TERAPI INSULIN PADA KASUS DIABETES MELLITUS TIPE 2 RAWAT JALAN DI KOTAMADYA DENPASAR
}

\author{
TOTAL COST OF INSULIN THERAPY FOR TYPE 2 DIABETES OUTPATIENT CASES IN \\ DENPASAR MUNICIPALITY
}

Luh Putu Febryana Larasanty*, I Gusti Ngurah Agung Dewantara Putra, Made Ary Sarasmita
Jurusan Farmasi, Fakultas MIPA, Universitas Udayana, Bali

\begin{abstract}
ABSTRAK
Insulin merupakan salah satu terapi obat untuk pasien diabetes mellitus (DM) tipe 2. Terdapat 4 jenis insulin berdasarkan onset kerjanya. Tiap jenis insulin memiliki besaran biaya dan effektivitasnya masing - masing. Telah banyak penelitian dilakukan untuk menilai effektivitas penggunaan insulin, di lain pihak penelitian yang membandingkan biaya total tiap jenis insulin masih sangat sedikit. Tujuan penelitian ini adalah untuk mengetahui total biaya yang dibutuhkan untuk terapi insulin pada pasien DM tipe 2 rawat jalan di rumah sakit kotamadya Denpasar. Penelitian ini merupakan penelitian deskriptif yang dilakukan pada bulan Maret sampai dengan bulan Juni 2016 di rumah sakit pemerintah di Kotamadya Denpasar. Subyek penelitian adalah pasien DM tipe 2 rawat jalan. Data regimen terapi insulin dan biayanya diperoleh dari rekam medis pasien, data resep, lembar administrasi, laporan terapi pasien pada instalasi farmasi dan juga riwayat sosial pasien. Total biaya dihitung berdasarkan biaya medis langsung (jasa dokter, tes laboratorium, biaya obat dan biaya penyiapan obat serta alat kesehatan), biaya non medis langsung (biaya administrasi dan transportasi) serta biaya non medis tidak langsung (hilangnya gaji/upah karena tidak masuk kerja). Terdapat 8 nama dagang insulin yang diresepkan untuk pasien DM tipe 2, dengan masing masing persentase penggunaannya adalah sebagai berikut: Apidra Solostar (12,50\%), Humalog Mix (4,35\%), Humalog Quickpen (3,80\%), Humulin N (2,17\%), Lantus Solostar (28,26\%), Levemir (11,96\%), Novomix $(1,09 \%)$ and Novorapid (35,87\%). Total biaya terendah regimen terapi insulin adalah penggunaan Lantus Solostar (Rp 528.480,-) dan total biaya tertinggi adalah Humalog Mix (Rp. 685.066,-). Rata - rata total biaya terapi insulin adalah sebesar Rp. $565.474,-$
\end{abstract}

Kata kunci : Diabetes mellitus tipe 2, insulin, terapi, total biaya

\begin{abstract}
Insulin is one of the drug therapy for type 2 diabetes patients. There are 4 types of insulin based on the onset of action, each type has its own cost and effectiveness. Has been a lot research about insulin effectiveness, however there was just few research reviewing about the total cost required for the insulin therapy. The purposes of this study is to determine of the total cost incurred for prescribed insulin therapy for type 2 diabetes outpatient in Denpasar municipality. This study was a descriptive study that conducted in March to June 2016 in General Hospital in Denpasar municipality. Research subject of this study was diabetic type 2 outpatient. Data of insulin therapy regimens and its costs obtained from patients' medical records, prescription data, administration sheet, patient therapy reports at the pharmacy as well as the social history of the patient. The total cost is calculated based on direct medical costs (physician services, laboratory tests, drugs and preparation cost of medicines and equipment), direct non-medical costs (administration fees and transport) and indirect non-medical costs (loss of salary / wages because they do not come to work). There were 8 branded names of insulin are prescribed for the diabetic patient, with it each percentage of use as follows: Apidra Solostar (12.50\%), Humalog Mix (4.35\%), Humalog Quickpen (3.80\%), Humulin N (2.17\%), Lantus Solostar (28.26\%), Levemir (11.96\%), Novomix (1.09\%) and Novorapid (35.87\%). Lowest total cost of prescribed insulin are Lantus Solostar (IDR 528.480,-), while the highest are Humalog Mix (IDR 685.066,-). The average total cost of insulin therapy is IDR 565.474,--.
\end{abstract}

Keywords: insulin, therapy, type 2 diabetes, total cost

\section{PENDAHULUAN}

Diabetes melitus (DM) tipe 2 merupakan salah satu penyakit degeneratif yang menjadi

Korespondensi :

Luh Putu Febryana Larasanty

Jurusan Farmasi FMIPA Universitas Udayana

Email : febryana@unud.ac.id faktor resiko berbagai penyakit kardiovaskular seperti stroke, penyakit jantung iskemik maupun penyakit gangguan ginjal kronik ${ }^{1}$. Penyakit DM tipe 2 merupakan jenis penyakit kronik yang membutuhkan biaya terapi yang besar. Pada tahun 2012, biaya medis yang dihabiskan untuk terapi pasien DM tipe 2 di 
Amerika Serikat mencapai 245 milyar dollar. Pasien dengan diagnosa DM tipe 2 menghabiskan biaya medis 2,3 kali lebih besar dibandingkan dengan yang tidak mengalami DM tipe 2. Sekitar $71,84 \%$ biaya medis yang dikeluarkan oleh pasien DM tipe 2 digunakan untuk biaya medis langsung yang berkaitan dengan terapi, termasuk di dalamnya adalah penyediaan obat - obatan antidiabetes ${ }^{2}$.

Insulin merupakan salah satu jenis obat antidiabetes yang merupakan terapi lini pertama untuk pasien DM tipe 2 yang memiliki kadar glukosa darah puasa $\geq 250 \mathrm{mg} / \mathrm{dL}$ dan kadar glukosa darah sewaktu $\geq 300 \mathrm{mg} / \mathrm{dL}^{3}$. Berdasarkan onset kerjanya, insulin dapat dibedakan menjadi empat tipe, yaitu insulin kerja cepat (rapid acting), insulin kerja pendek (short acting), insulin kerja menengah (intermediate acting) dan insulin kerja panjang (long acting). Penggunaan terapi insulin diharapkan dapat mampu meniru pola sekresi insulin fisiologis yakni sekresi insulin basal dan insulin prandial ${ }^{18}$. Insulin basal adalah jenis insulin yang dibutuhkan untuk mengkontrol flukstuasi kadar glukosa darah sepanjang hari, sedangkan insulin prandial merupakan jenis insulin yang dibutuhkan untuk mengontrol fluktuasi kadar glukosa darah postprandial20.

Penelitian mengenai perbandingan effektivitas penggunaan insulin telah banyak dilaporkan, namun penelitian mengenai total biaya penggunaan regimen terapi insulin masih sangat jarang ${ }^{4,10}$. Penelitian ${ }^{12,19}$ merupakan contoh penelitian mengenai penggunaan insulin dan jumlah biaya yang harus dikeluarkan untuk memperoleh regimen terapi insulin tersebut. Pembiayaan yang dihitung dalam penelitian lebih banyak mengenai total biaya medis langsung yaitu biaya yang dikeluarkan yang berkaitan dengan pelayanan kesehatan langsung dan biaya atas obat dan alat kesehatan yang diperoleh. Penelitian mengenai analisis biaya $^{2}$ penyakit diabetes mellitus, di Indonesia dimana perhitungan biaya juga berdasarkan hanya pada rincian biaya medis langsung. Oleh karena itu perlu dilakukan penelitian mengenai perhitungan total biaya terapi insulin pada pasien DM tipe 2 rawat jalan. Dimana perhitungan total biaya mencakup biaya medis langsung, biaya non medis langsung dan biaya non medis tidak langsung.

\section{METODE}

\section{Rancangan Penelitian}

Penelitian ini merupakan penelitian deskriptif yang dilakukan pada bulan Maret sampai dengan bulan Juni 2016 di rumah sakit pemerintah yang ada di Kotamadya Denpasar.

\section{Subjek Penelitian}

Populasi penelitian adalah seluruh pasien DM tipe 2 rawat jalan tanpa penyakit penyerta dan berdomisili di wilayah kotamadya Denpasar. Kriteria inklusi dalam penelitian adalah pasien yang mendapatkan terapi insulin tunggal atau terapi insulin kombinasi dan bersedia ikut dalam penelitian (menandatangani lembar Informed Consent). Kriteria eksklusi dalam penelitian ini adalah pasien DM tipe 2 dengan penyakit penyerta serta pasien dengan data resep, lembar administrasi dan/atau rekam medis yang tidak lengkap. Seluruh pasien yang memenuhi kriteria inklusi serta tidak memenuhi kriteria eksklusi selama periode penelitian diambil sebagai subjek penelitian.

\section{Pengumpulan dan Analisa Data}

Data regimen terapi insulin dan biayanya diperoleh dari rekam medis pasien pada bagian rekam medis, lembar administrasi rumah sakit, data resep dan laporan terapi pasien pada instalasi farmasi. Riwayat sosial pasien diambil dari rekam medis pasien dan dikonfirmasi dengan melakukan wawancara kepada pasien. Total biaya dihitung berdasarkan biaya medis langsung (jasa dokter, tes laboratorium, biaya obat dan biaya penyiapan obat serta alat kesehatan), biaya non medis langsung (biaya administrasi dan transportasi) serta biaya non medis tidak langsung (hilangnya gaji/upah karena tidak masuk kerja).

Data dianalisis secara deskriptif untuk mengetahui demografi pasien (usia, jenis kelamin, wilayah tempat tinggal, pekerjaan pasien dan jenis insulin yang diperoleh). Alamat tempat tinggal pasien di input pada aplikasi google map untuk mengetahui jarak antara 
tempat tinggal ke rumah sakit tempat pasien rawat jalan. Biaya transportasi dihitung berdasarkan jarak tempuh (pergi pulang) dalam satuan kilometer dikalikan nilai biaya operasional kendaraan di kotamadya Denpasar. Nilai hilangnya gaji/upah karena tidak masuk kerja dihitung berdasarkan nilai gaji/upah pokok pasien dibagi jumlah hari kerja effektif dalam bulan yang bersangkutan. Untuk pegawai swasta atau wiraswasta dengan pendapatan tidak tetap, gaji/upah dihitung menggunakan pendekatan upah minimum kotamadya Denpasar perbulan dibagi hari kerja effektif pada bulan yang bersangkutan. Masingmasing biaya dikelompokan berdasarkan klasifikasinya, kemudian di total sehingga mendapatkan total biaya terapi secara keseluruhan.

\section{HASIL DAN PEMBAHASAN}

\section{Demografi Subjek Penelitian}

Total pasien DM tipe 2 rawat jalan yang menjadi subjek penelitian berjumlah 184 orang. Sebaran data demografi pasien dapat dilihat pada gambar 1. Sebagian besar pasien berjenis kelamin laki-laki (55,98\%). Penelitian ${ }^{2,7}$ menunjukkan hasil yang sama, dimana rasio pasien dengan jenis kelamin laki - laki pada kasus diabetes mellitus tipe 2 lebih tinggi dibandingkan dengan pasien berjenis kelamin perempuan. Angka kejadian yang lebih tinggi pada laki - laki dapat disebabkan karena adanya insidensi peningkatan diagnosa kejadian diabetes melitus pada laki - laki sejak tahun 2010 yaitu sebesar $177 \%$.

Berdasarkan kelompok usia, terlihat adanya peningkatan jumlah pasien seiring dengan peningkatan kelompok usia, dimana jumlah pasien DM tipe 2 paling banyak ada pada kelompok usia 55 tahun sampai dengan 64 tahun, kemudian mengalami penurunan pada kelompok usia berikutnya. Hal ini sesuai dengan hasil riset pusat data dan informasi ${ }^{14}$, dimana angka kejadian dari diabetes melitus tipe 2 meningkat seiring dengan peningkatan usia. Penurunan jumlah pasien pada kelompok usia $\geq 65$ tahun dapat disebabkan karena pasien yang termasuk kategori usia lanjut ( $\geq 65$ tahun) umumnya lebih banyak menderita penyakit penyerta $^{8}$ sehingga tidak menjadi subjek penelitian.

Data demografi pekerjaan pasien diperlukan dalam perhitungan biaya non medis tidak langsung yaitu hilangnya gaji/upah karena tidak masuk kerja. Pasien dengan pekerjaan sebagai pegawai negeri sipil adalah sebesar $39,53 \%$ dan merupakan jenis pekerjaan yang paling banyak. Berdasarkan riwayat sosial pasien pada rekam medis dan konfirmasi kepada pasien, golongan tertinggi pasien dengan pekerjaan PNS adalah golongan IVa dengan gaji pokok sebesar Rp. 4.616.600,- per bulan berdasarkan peraturan pemerintah Republik Indonesia ${ }^{14}$. Pada kelompok pekerjaan pegawai swasta, terdapat pasien yang memiliki gaji pokok tetap yaitu pasien yang bekerja di perusahaan swasta. Namun terdapat pula pasien pegawai swasta dengan penghasilan tidak tetap dan kelompok pekerja wiraswasta dengan penghasilan yang fluktuatif, sehingga perhitungan gaji/upah untuk biaya non medis tidak langsung di dasarkan pada nilai upah minimum regional (UMR) kotamadya Denpasar yaitu sebesar Rp. 2.007.000,- per bulan ${ }^{13}$.

Berdasarkan tempat tinggal, hasil penelitian menunjukkan tempat tinggal pasien menyebar merata pada 4 kecamatan di kotamadya Denpasar. Pasien paling banyak berdomisili di kecamatan Denpasar Timur yaitu sebesar 27,91\%, dengan perbedaan sebesar $6,98 \%$ dengan pasien yang berdomisili di Denpasar Utara sebagai tempat domisili yang paling sedikit. Tempat domisili di gunakan dalam perhitungan biaya transportasi menuju dan kembali dari tempat rawat jalan. Biaya transport dihitung dengan menggunakan biaya operasional kendaraan di kotamadya Denpasar ${ }^{6}$ yaitu sebesar Rp.3.119,-.

\section{Total Biaya Terapi Insulin}

Hasil penelitian (Tabel I) menunjukkan bahwa terdapat total 4 jenis insulin dengan 8 nama dagang yang digunakan oleh pasien yang menjadi subjek penelitian. Rapid acting insulin merupakan jenis insulin yang paling banyak diresepkan untuk pasien DM tipe 2 rawat jalan di rumah sakit umum kotamadya Denpasar dengan total penggunaan sebesar 52,17\%. 


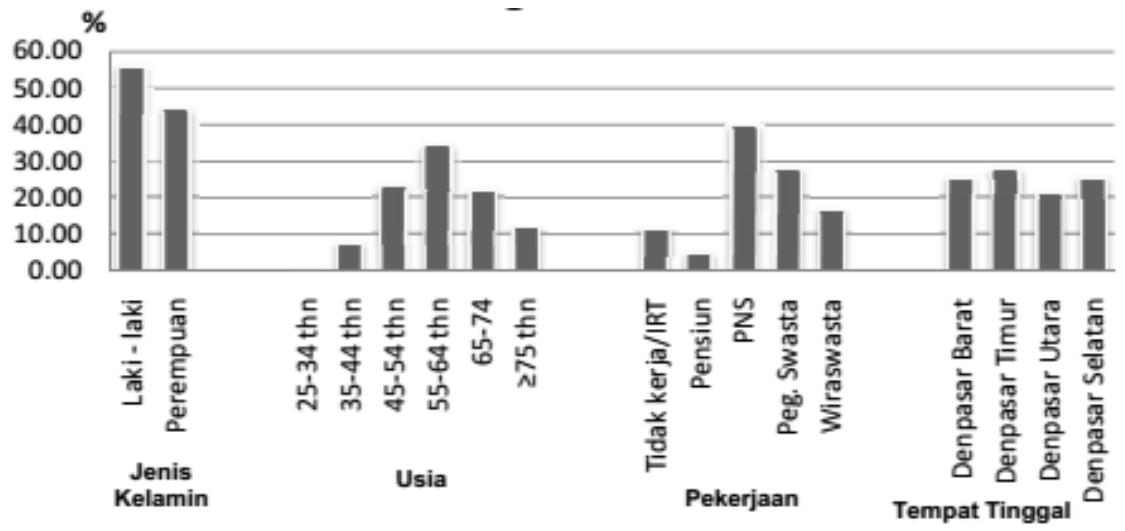

Gambar 1. Data Demografi Pasien DM Tipe 2 Rawat Jalan di Rumah Sakit Umum Kotamadya Denpasar

Tabel I. Regimen Terapi Insulin pada Pasien DM Tipe 2 Rawat Jalan di Rumah Sakit Umum Kotamadya Denpasar

\begin{tabular}{|c|c|c|c|}
\hline Jenis Insulin & Nama Insulin & Jumlah & Persentase (\%) \\
\hline \multirow[b]{2}{*}{ Long acting } & Levemir & 22 & 11,96 \\
\hline & Lantus solostar & 52 & 28,26 \\
\hline \multirow[t]{2}{*}{ Intermediet acting } & Humulin $n$ & 4 & 2,17 \\
\hline & Novorapid & 66 & 35,87 \\
\hline \multirow[t]{2}{*}{ Rapid acting } & Humalog quickpen & 7 & 3,80 \\
\hline & Apidra solostar & 23 & 12,50 \\
\hline \multirow{2}{*}{ Premixed } & Novomix & 2 & 1,09 \\
\hline & Humalog mix & 8 & 4,35 \\
\hline Total & & 184 & 100,00 \\
\hline
\end{tabular}

Kemudian terdapat golongan long acting insulin dengan persentase penggunaan sebesar $40,22 \%$ pada posisi kedua. Hasil yang diperoleh pada penelitian ini sesuai dengan hasil penelitian ${ }^{5}$ mengenai pola penggunaan insulin pada pasien diabetes mellitus tipe 2. Rapid acting insulin merupakan jenis insulin bolus. Jenis insulin ini digunakan sebagai terapi augmentasi pada pasien diabetes melitus tipe 2. Insulin bolus digunakan untuk mengatasi peningkatan glukosa setelah makan dan mempertahankan kadar glukosa darah 2 jam postprandial 1,15. Long acting insulin merupakan jenis insulin basal. Jenis insulin ini merupakan terapi lini pertama pada pasien yang baru pertama kali memperoleh insulin. Penggunaan insulin basal merupakan jenis insulin yang paling nyaman dari aturan pakai dan biaya yang lebih murah dibandingkan insulin bolus ${ }^{1}$.

Perhitungan biaya penggunaan insulin perbulan pada pasien DM tipe 2 rawat jalan di Kotamadya Denpasar (Tabel II). Biaya medis langsung adalah biaya yang dikeluarkan pasien untuk membayar produk medis dan pelayanan untuk mencegah, deteksi, dan atau menyembuhkan penyakit. Biaya medis langsung yang dihitung dalam penelitian ini meliputi jasa dokter, tes laboratorium, biaya obat dan biaya penyiapan obat serta alat kesehatan. Hasil penelitian menunjukan bahwa Humulin N (intermediet acting insulin) memberikan total biaya medis paling rendah yaitu sebesar Rp. 347.864,-- Humulin N adalah insulin basal dengan kandungan insulin NPH. 
Tabel II. Rincian Biaya Penggunaan Insulin Perbulan pada Pasien DM Tipe 2 Rawat Jalan di Rumah Sakit Umum Kotamadya Denpasar

\begin{tabular}{|c|c|c|c|c|}
\hline Insulin & $\begin{array}{c}\text { Biaya Medis } \\
\text { Langsung }\end{array}$ & $\begin{array}{c}\text { Biaya Non Medis } \\
\text { Langsung }\end{array}$ & $\begin{array}{l}\text { Biaya Non Medis } \\
\text { Tidak Langsung }\end{array}$ & Total Biaya \\
\hline Levemir & Rp 354.632 & $\operatorname{Rp} 97.517$ & $\operatorname{Rp} 79.256$ & $\operatorname{Rp} 531.405$ \\
\hline Lantus Solostar & Rp 357.374 & $\operatorname{Rp} 91.352$ & $\operatorname{Rp} 79.754$ & $\operatorname{Rp} 528.480$ \\
\hline Humulin $\mathrm{N}$ & $\operatorname{Rp} 347.864$ & $\operatorname{Rp} 111.265$ & Rp 79.142 & $\operatorname{Rp} 538.272$ \\
\hline Novorapid & $\operatorname{Rp} 387.548$ & Rp 94.192 & $\operatorname{Rp} 79.388$ & $\operatorname{Rp} 561.128$ \\
\hline Humalog Quickpen & $\operatorname{Rp} 383.495$ & $\operatorname{Rp} 101.604$ & Rp 79.461 & $\operatorname{Rp} 564.561$ \\
\hline Apidra Solostar & $\operatorname{Rp} 391.170$ & $\operatorname{Rp} 99.224$ & Rp 79.679 & $\operatorname{Rp} 570.073$ \\
\hline Novomix & $\operatorname{Rp} 372.461$ & $\operatorname{Rp} 92.772$ & $\operatorname{Rp} 79.571$ & $\operatorname{Rp} 544.804$ \\
\hline Humalog Mix & Rp 517.152 & $\operatorname{Rp} 88.635$ & Rp 79.279 & $\operatorname{Rp} 685.066$ \\
\hline RERATA & Rp 388.962 & $\operatorname{Rp} 97.070$ & $\operatorname{Rp} 79.441$ & $\operatorname{Rp} 565.474$ \\
\hline
\end{tabular}

Penggunaan insulin NPH berdasarkan penelitian ${ }^{19}$ memberikan total biaya medis yang lebih rendah dibandingkan jenis insulin basal lainnya dan jenis premixed insulin. Hasil penelitian tersebut ${ }^{19}$ sesuai dengan yang diperoleh dalam penelitian ini, dimana Humulin $\mathrm{N}$ memberikan total biaya medis lebih rendah dibandingkan insulin basal lainnya (levemir dan lantus) serta premixed insulin (novomix dan humalog mix).

Biaya non medis langsung adalah biaya untuk membayar pelayanan dan bukan untuk biaya perawatan medis. Biaya non medis langsung yang dihitung dalam penelitian ini adalah biaya administrasi dan biaya transportasi. Biaya administrasi mengikuti ketetapan biaya administrasi masing - masing rumah sakit yaitu berdasarkan kelas perawatan dan tipe rumah sakit. Besaran biaya transportasi menggunakan perhitungan tarif biaya operasional kendaraan di kotamadya Denpasar per kilometer jarak tempuh pergi pulang pasien berdasarkan penelitian ${ }^{6}$. Kisaran biaya non medis langsung pada penelitian ini adalah Rp. 88.635 sampai dengan $\mathrm{Rp}$. 111.265 .

Biaya non medis tidak langsung adalah biaya yang mengurangi produktivitas. Biaya non medis tidak langsung yang dihitung dalam penelitian ini adalah hilangnya gaji/upah karena tidak masuk kerja. Berdasarkan wawancara yang dilakukan pada pasien, pasien dengan pekerjaan PNS tidak mengalami pengurangan gaji pokok karena tidak masuk kerja dengan keterangan sakit. Pasien yang telah pensiun dan pasien yang tidak bekerja/IRT juga tidak menyumbangkan biaya non medis langsung. Sehingga biaya non medis tidak langsung hanya berasal dari pasien dengan pekerjaan pegawai swasta dan wiraswasta. Berdasarkan data biaya non medis dapat dihitung besar pengeluaran pasien yang tidak berkaitan dengan biaya medis langsung. Rata - rata pengeluaran pasien untuk biaya non medis adalah sebesar Rp. 176.511,per bulan yaitu sebesar $31,21 \%$ dari total biaya regimen insulin.

Hasil penelitian menunjukkan bahwa total biaya penggunaan insulin per bulan berada pada kisaran Rp. 528.480 (Lantus solostar) sampai dengan Rp 685.066 (Humalog mix), dengan rata - rata biaya total sebesar Rp. 565.474. Alokasi biaya medis langsung adalah sebesar $68,79 \%$ dari total biaya keseluruhan. Singh ${ }^{17}$ melaporkan bahwa sebagian besar total biaya terapi diabetes mellitus tipe 2 memang berkaitan dengan biaya medis langsung, dimana pada penelitian tersebut biaya medis langsung mencapai $86,63 \%$ dari total biaya keseluruhan. Jenis terapi yang diperoleh pasien merupakan faktor penentu yang kuat dari total biaya yang dibutuhkan untuk penanganan diabetes mellitus tipe $2^{16}$.

Perhitungan total biaya penggunaan insulin pada pasien DM tipe 2 menunjukkan 
bahwa pasien yang memperoleh terapi insulin tidak hanya mengeluarkan biaya untuk terapi medis yang diperlukan untuk penyakit DM tipe 2 yang dideritanya, namun juga mengeluarkan biaya untuk pengurangan produktivitas dan pelayanan non medis. Hasil penelitian menunjukkan bahwa alokasi biaya non medis langsung sebesar $17,17 \%$ dan biaya non medis tidak langsung sebesar $14,05 \%$. American Diabetes Association ${ }^{1}$ menyatakan bahwa pengurangan produktivitas dan peningkatan kebutuhan akan pelayanan non medis karena penyakit diabetes mencapai angka 20\% dari total pengeluaran kesehatan dan terus meningkat setiap tahunnya. Dimana peningkatan biaya non medis juga dikaitkan dengan menurunnya produktivitas saat kerja, meningkatnya jumlah hari tidak masuk kerja dan hilangnya kapasitas produksi karyawan ${ }^{1}$.

Penelitian ini memiliki beberapa kekurangan, antara lain adalah perhitungan total biaya insulin dilakukan hanya untuk biaya medis langsung, biaya non medis langsung dan biaya non medis tidak langsung dan belum memperhitungkan biaya tak teraba seperti rasa tidak nyaman maupun rasa sakit yang berhubungan dengan kondisi patologis yang di derita pasien. Kekurangan yang lain adalah tidak dihitungnya biaya medis yang timbul karena munculnya efek samping obat yang mungkin dirasakan pasien dan biaya tambahan untuk makanan, minuman atau alat kesehatan yang diperlukan oleh pasien. Sehingga kemungkinan total biaya riil akan semakin besar. Hasil penelitian ini dapat menjadi gambaran bahwa dalam terapi insulin pada pasien DM tipe 2 atau terapi obat lainnya, masing - masing regimen obat dalam kelas terapi yang sama dapat memberikan perbedaan biaya dalam rangka mencapai effektivitas terapi tertentu yang diharapkan. Selain itu terdapat biaya lain selain biaya medis langsung yang dapat mempengaruhi pengeluaran pasien untuk memperoleh pengobatan yang diperlukan.

\section{KESIMPULAN}

Hasil penelitian menunjukkan rata - rata total biaya yang dibutuhkan untuk terapi insulin pada pasien DM tipe 2 rawat jalan di rumah sakit kotamadya Denpasar tiap bulannya adalah sebesar Rp. 565.474. Total biaya terendah adalah pada penggunaan Lantus Solostar sebesar Rp. 528.480 dan yang tertinggi adalah pada penggunaan Humalog Mix sebesar Rp 685.066. Alokasi biaya adalah untuk biaya medis langsung sebesar $68,79 \%$ dan biaya non medis sebesar $31,21 \%$.

\section{UCAPAN TERIMAKASIH}

Penulis mengucapkan terima kasih kepada seluruh pasien yang bersedia ikut serta dalam penelitian ini. Penulis mengucapkan terima kasih kepada Direktorat Riset dan Pengabdian kepada Masyarakat Kementerian Riset, Teknologi, dan Pendidikan Tinggi yang melalui Lembaga Penelitian dan Pengabdian Masyarakat Universitas Udayana memberikan dana hibah penelitian pada skim penelitian Hibah Bersaing.

\section{PERNYATAAN PENULIS}

Abstrak penelitian ini telah didesiminasikan dalam bentuk poster pada pertemuan ilmiah Federation of Asian Pharmaceutical Associations (FAPA) 2016.

\section{DAFTAR PUSTAKA}

1. American Diabetes Association. Economic costs of diabetes in the U.S. in 2012. Diabetes Care 2013; 36:1033-1046. Diabetes Care. 2013; 36(6):1797-1797. doi:10.2337/ dc13-er06.

2. Fitri, E., Andayani, T.M., Suparniati E. Analisis Biaya Penyakit Diabetes Mellitus. JMPF. 2015;5(1):61-66.

3. Garty, M., McCance, D, R., Hanson, R.L., Charles MA. Monitoring of glycated hemoglobin level in hospitalized diabetic patients with heart failure. Singapore Medicat J. 2006; 15:132-138.

4. Hermansen, K., Davies, M., Derezinski, T., Martinez, R.G., Clauson, P., Home, P. A 26 Week, Randomized, Parallel, TreatTo-Target Trial Comparing Insulin Detemir With NPH Insulin as Add-On Therapy to Oral Glucose-Lowering Drug in Insulin Naïve People With Type 2 Diabetes. Dia Care. 2006;26(6):1269-1274. 
5. Ikeda, S., Crawford, B., Sato M. Utilization Patterns of Insulin Therapy and Healthcare Services Among Japanese Insulin Initiators During Their First Year: A Descriptive Analysis of Administrative Hospital Data. Biomed Cent Heal Serv Res. 2016;16(6):1-11.

6. Indrayana, I.G.N.G.A, Wedagama, D.M.P., Suparsa, I.G.P. Analisis Kerja Ruas Jalan dan Biaya Perjalanan Akibat Tindaan Ruas Jalan. J Ilm Elektron Tek Sipil,. 2013;2(2):1-7.

7. Kartika, I.G.A.A, Lestari, A.A.W, Swastini, D.A. Perbandingan Profil Penggunaan Terapi Kombinasi Insulin pada Pasien Diabetes Mellitus Tipe 2 di Unit Rawat Inap Rumah Sakit Umum Pusat Sanglah. J Farm Udayana. 2013;2(2):62-69.

8. Kirkman MS, Briscoe VJ, Clark N, et al. Diabetes in older adults. Diabetes Care. 2012;35(12):2650-2664. doi:10.2337/dc121801.

9. Kirkman, M.S., Briscoe, V.J., Clark, N. et al. Diabetes in Older Adults. Diabetes Caree. 2012;32(12):2650-2664.

10. Mannucci, E., M. Monami NM. ShortActing Insulin Analogues Vs. Reguler Human Insulin in Type 2 Diabetes: A Meta-Analysis. J Compil Blackwell Publ Ltd. 2008; 11:53-59.

11. Mayfield JA, White RD. Insulin therapy for type 2 diabetes: Rescue, augmentation, and replacement of beta-cell function. Am Fam Physician. 2004;70(3):489-500+511.

12. Oishi M, Yokoyama $\mathrm{H}, \mathrm{Abe} \mathrm{N}$, et al. Time and Costs of Insulin Treatment in the Care of Newly Registered Type 2 Diabetes Patients in Diabetes Clinics Across Japan (JDDM 22). Japanese Clin Med. 2011; 2:43-51. doi:10.4137/JCM.S7736.
13. Peraturan Gubernur Bali. Peraturan Gubernur Bali No. 1 Tahun 2016 Tentang Upah Minimum Kabupaten/Kota. Bali; 2016.

14. Peraturan Pemerintah Republik Indonesia. Peraturan Pemerintah Republik Indonesia No. 30 Tahun 2015 Tentang Perubahan Ketujuh Belas Atas Peraturan Pemerintah Nomor 7 Tahun 1977 Tentang Peraturan Gaji Pegawai Negeri Sipil.; 2015.

15. Petznick A. Insulin management of type 2 diabetes mellitus. Am Fam Physician. 2011;84(2):183-190. doi: 10.1016/j.mcna.2004.04.002.

16. Shuyu Ng C, Toh M, Ko Y, Lee J. Direct medical cost of type 2 diabetes in Singapore. PLoS One. 2015;10(3):1-11. doi: 10.1371/journal.pone.0122795.

17. Singh, A., Dutta, S.B., Varma, A., Beg, M.A., Kumar, H., Kaur, A. A Drug Utilization and Pharmacoeconomic Study of Anti-Diabetic Drugs Prescribed to Type 2 Diabetes Mellitus Patients Visiting the Medicine Out-Patient Department of a Tertiary Care Hospital of North India. Int J Basic Clin Pharmacol. 2016;5(4):1220 1227.

18. Soegondo, S., Soewondo, P., Subekti I. Konsensus Pengelolaan dan Pencegahan Diabetes Melitus Tipe 2 di Indonesia. Perkumpulan Endokrinol Indones. 2006.

19. Svensson A-M, Lak V, Fard MP, Eliasson B. Total costs of basal or premixed insulin treatment in 5077 insulin-na\{"i\} ve type 2 diabetes patients: register-based observational study in clinical practice. Clin Diabetes Endocrinol. 2015;1(1):1-6. doi:10.1186/s40842-015-0017-1.

20. Triplitt, A.K., Reasner, C.A., and Isley W. Diabetes Mellitus. in Dipiro. In: Pharmacotherapy: A Pathophysiologic Approach. 7th ed. New York: McGraw Hill; 2008. 